\title{
Simulating the electrical characteristics of a photovoltaic cell based on a single-diode equivalent circuit model
}

\author{
Syeda Adila Afghan ${ }^{1 *}$,Husam Almusawi ${ }^{2}$,Husi Geza ${ }^{3}$ \\ ${ }^{1}$ University of Debrecen, Doctoral School of Informatics, adila@eng.unideb.hu, Pakistan \\ ${ }^{2}$ University of Debrecen, asd_sw@ymail.com, Hungary \\ ${ }^{3}$ University of Debrecen, husigeza@eng.unideb.hu, Hungary
}

\begin{abstract}
This research work presents the simulation based study of a commercial solar cell for analyzing the real-time behavior of a PV module. The mathematical modelling is based on Equivalent circuit of the solar cell and demonstrating the practical approach for using the single diode five parameters (IM5P) mechanism. This research involves purely mathematical formulation to extract the unknown parameters of PV cell by applying the Lambert $\mathrm{W}$ function. The $\mathrm{I}-\mathrm{V}$ and $\mathrm{P}-\mathrm{V}$ characteristics are emulated under different temperature and radiation levels by using the Linear Technology's LTSpice simulator.
\end{abstract}

\section{Introduction}

The world is facing huge energy crises and we will run out of fuel coal and gases by 2071 as it is predicted by CIA (Central Intelligence Agency) [1].This is an alarming situation which emphasizes the researchers and scientists around the globe to make alternative possible solutions. Energy harvesting is the only hope to overcome this issue, however, renewable energy sources can be utilized to tackle most of the energy hungry devices whether it is in form of a large-scale applications like solar systems power generators or a small scale domestic use like cell phone, Ipods, and wireless sensor networks, elaborated in a recent review by A. S. Adila, A. Husam, J. H. Sana G. Husi [2]. The most viable source which can equip greener ways successfully since last decade is solar energy.

The Photovoltaic market have seen rapid growth for solar power systems that entertains the possible gap of renewable energy interpretation for both macro and micro systems as reported in Ren21 [3]. A Photovoltaic system converts the sunlight directly into electricity and the main device is solar cell in the system. Solar cell arrays are formed by grouping them together. The electronic converters play a viable role for processing the electricity from the PV system as defined by M. G. Villalva, J. R. Gazoli, E. R. Filho [4]. A solar cell is made of semiconductor diode which is exposed to light and consists of various types of semiconductors using different manufacturing processes as reviewed by A. S. Sedra, K. C. Smith [5]. M.A. Eltawil, Z. Zhao discussed that the incoming solar radiations and the intrinsic properties are responsible for the electric energy generation in a solar cell [6]. The solar radiation is composed of photons of various energies, some of them are absorbed at p-n junction as shown in Fig 1., described in Union of Concerned Scientists [7]. If the photons with energies are lower than the bandgap of the solar cell, they are useless and will not generate electric current or voltage. Whereas, photons with energy higher than the bandgap will generate electricity and the energy corresponding to the bandgap will be used only. The remaining energy is dissipated as heat in the body of solar cell as mentioned by J. Bikaneria, S. P. Joshi, A. R. Joshi [8].

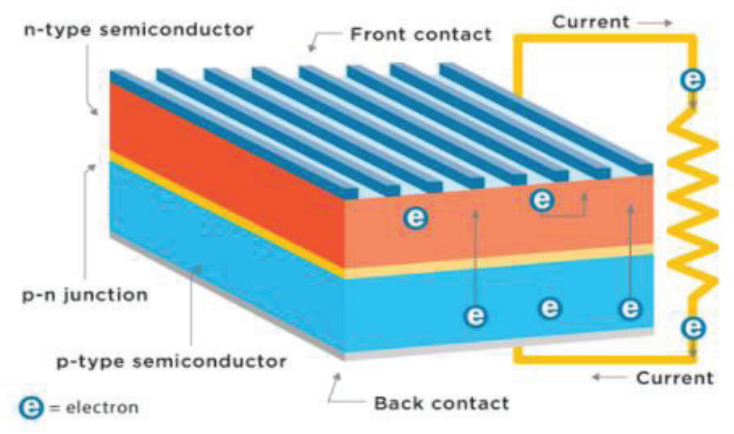

Fig 1. Schematic diagram demonstrating the operation of $p-n$ junction of a Solar Cell

\footnotetext{
"Corresponding author: adila@eng.unideb.hu
} 
Despite of widely adopted renewable solar solution, there's still lack of understanding the performance efficiency and power extraction, when it comes to the selection of solar panels or arrays by the end users. Many mathematical models are highlighted for demonstrating the non-linear response of a PV system as highlight by E. M. G. Rodrigues, R. Melicio, V. M. F. Mendes and J. P. S. Catalao [9]. The common technique is to model the solar equivalent circuit and amongst all possible parametric models, the single diode model is the popular one, which is also known as 1M5P (Single Mechanism, Five Parameters). It is used to predict the real-time behavior of a solar cell mentioned by Yetayew and Jyothsna [10]. For I - V and P - V characteristics, the complicated procedure is required which involves certain equations and calculations. The solar cell involves non-linear and exponential expressions that results the equations as implicit, which is complicated, iterative, and time consuming. J. Cubas, S. Pindado, C. D. Manuel [11] demonstrated in their research that the explicit technique is required which consists of analytical formulation with use of Lambert $\mathrm{W}$ function for making the parametric model simpler. In this paper, the single diode equivalent circuit is being modelled for a commercial solar cell for obtaining the unknown parameters from the manufacturer's datasheet. Matlab is used for the formulation of the explicit expressions whereas, the LTSpice circuit simulator is used to model and simulate the performance of solar cell by demonstrating the $\mathrm{I}-\mathrm{V}$ and $\mathrm{P}-\mathrm{V}$ curves at temperature and irradiations variations of solar equivalent circuit.

\section{Modelling of solar cell}

\subsection{Ideal single diode model for photovoltaic cell}

The photovoltaic technology is based on the principle of electron hole creation in each cell that consists of two different layers; $\mathrm{p}$ type and $\mathrm{n}$ type. However, The I - V curve characteristics of a solar cell are like the exponential characteristics of the ideal diode as described by Walker [12]. To understand the phenomenon of any solar cell, panel or an array, it is needed to derive the electrical parameters of PV cell in to the equivalent circuit as a necessary requirement.

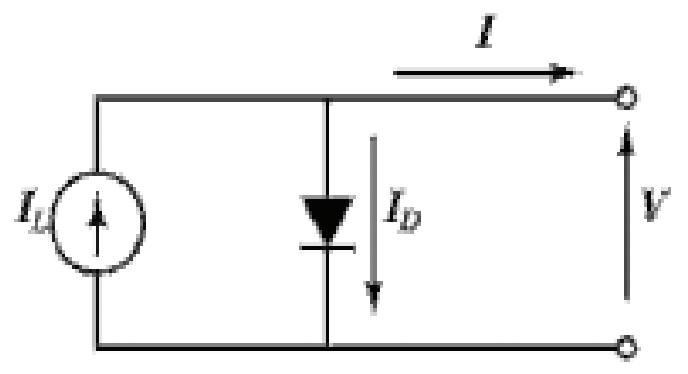

Fig. 2. Ideal Single Diode Model (1M3P)
As shown in the Fig. 2, the ideal solar cell consists of current source $I_{L}$, which is parallel to the diode $I_{D}$. The model containing 3 parameters also known as $1 \mathrm{M} 3 \mathrm{P}$ (Single mechanism three parameters) suggested by $\mathrm{M}$. Azzouzi, D. Popescu and M. Bouchahdane [13].

Therefore, the equation can be derived by using the Kirchhoff's law:

Where $\mathrm{I}_{\mathrm{D}}$ equals to,

$$
\mathbf{I}=\mathbf{I}_{\mathbf{L}}-\mathbf{I}_{\mathbf{D}}
$$

$$
I_{D}=I_{O}\left[\exp \left(\frac{V}{A V_{T}}\right)-1\right]
$$

The output current is represented by the following non-linear I - V equation:

$$
I=I_{L}-I_{O}\left[\exp \left(\frac{V}{A V_{T}}\right)-1\right]
$$

However, this model does not be able to produce accurate results for modelling $\mathrm{I}-\mathrm{V}$ and $\mathrm{P}-\mathrm{V}$ curves of a solar cell.

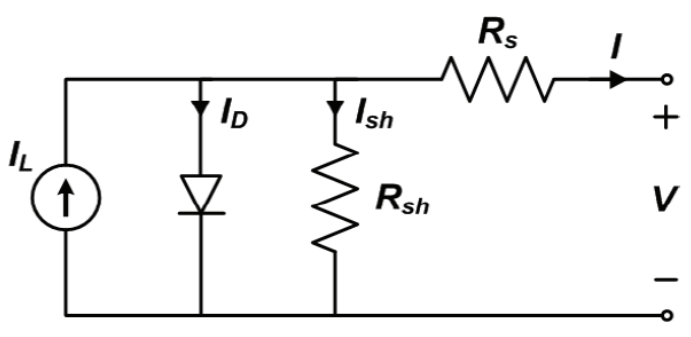

Fig. 3. Single Diode Equivalent Circuit (1M5P)

\subsection{Single diode model with series and shunt resistors}

To specify the most popular and practical functioning of a solar cell, M. Wolf and H. Rauschenbach [14] denoted the representation of losses by the resistors as shown in the Fig. 3, having a current source connected in parallel with a diode and two resistors, one in series and other in parallel.

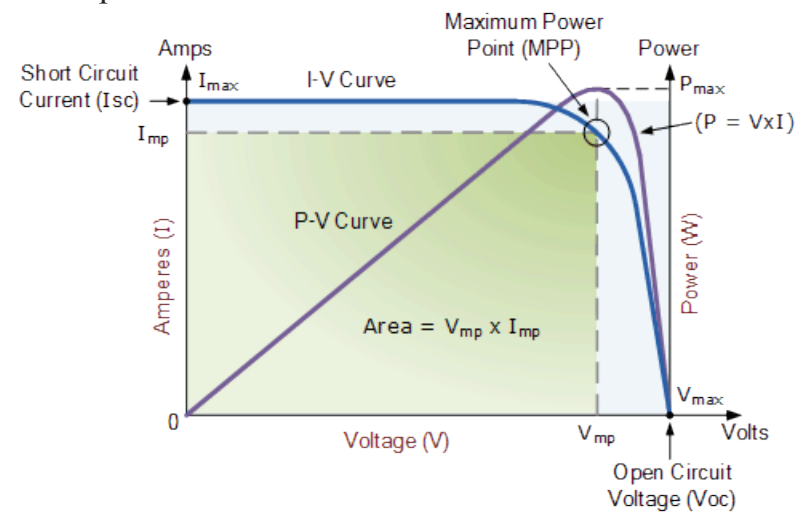

Fig. 4. $\mathrm{I}-\mathrm{V}$ and $\mathrm{P}-\mathrm{V}$ characteristics of a typical solar cell

Azzouzi, Popescu and Bouchahdane [13] also mentioned that this model composed of five parameters for which it known as 1M5P (Single mechanism, five parameters), as current, voltage, and power curves can be easily deduced by this model by calculating the five unknown parameters. Mostly the short circuit, open

\footnotetext{
*Corresponding author: adila@eng.unideb.hu
} 
circuit and maximum power points are included in the datasheet of solar cells as illustrated in Fig. 4.

\section{Mathmatical modeling of single diode equivalent circuit}

A. Wafaa, A. M. Ashraf, A. Fouad, S. Saad [15] described that it is important to derive the characteristics equations for solar cell for calculating the fiveparameters of an equivalent solar circuit. Considering the Fig. 3, the equation is given as:

$$
\mathbf{I}=\mathbf{I}_{\mathbf{L}}-\mathbf{I}_{\mathbf{D}}-\mathbf{I}_{\text {sh }}
$$

To fully define the relationship between the output current of photovoltaic cell and the terminal voltage for the single diode model is given by the following equation:

$$
I=I_{L}-I_{0}\left[\exp \left(\frac{V+I R_{s}}{a V_{T}}\right)-1\right]-\frac{V+I R_{s}}{R_{s h}}
$$

$$
\text { Along with Thermal Voltage; } V_{T}=n \frac{K T}{q}[\mathrm{~V}]
$$

Where $\boldsymbol{I}_{\boldsymbol{L}}$ denotes the current generated by the incidence of light, $\boldsymbol{I}_{\boldsymbol{D}}$ denotes the diode current, $\boldsymbol{R}_{\boldsymbol{S}}$ represents the series resistance, for leakage current $\boldsymbol{R}_{\boldsymbol{s} h}$ is denoted as Shunt resistor, $\boldsymbol{a}$ is the ideality factor, $\boldsymbol{V} \boldsymbol{t}$ is the thermal voltage, $\boldsymbol{q}$ as an electron charge, the Boltzman constant $\boldsymbol{K}$; the $\boldsymbol{n}$ as number of cells in series and $\boldsymbol{T}$ as the temperature.

Solar cell is required to be characterized by the short circuit current Isc, the open circuit voltage $\boldsymbol{V o c}$, and ideality factor $\boldsymbol{a}$. Equation (4) can be rewritten as:

Short Circuit current: $\mathrm{I}=\mathrm{Isc}$, for $\mathrm{V}=0$

$$
I_{s c}=I_{L}-I_{0}\left[\exp \left(\frac{I_{s c} R_{s}}{a V_{T}}\right)-1\right]-\frac{I_{s c} R_{s}}{R_{s h}}
$$

Open circuit Voltage: $\mathrm{I}=0$ for $\mathrm{V}=\mathrm{Voc}$

$$
0=I_{L}-I_{o}\left[\exp \left(\frac{V_{o c}}{a V_{T}}\right)-1\right]-\frac{V_{o c}}{R_{s h}}
$$

Maximum power point equation: $\mathrm{I}=\mathrm{Imp}$, for $\mathrm{V}=$ Vmp

$$
I_{m p}=I_{L}-I_{0}\left[\exp \left(\frac{V_{m p}+I_{m p} R_{s}}{a V_{T}}\right)-1\right]-\frac{V_{m p}+I_{m p} R_{s}}{R_{s h}}
$$

\subsection{Required equations for calculating unknown parameters}

In order to obtain the value of series resistor, it is need to calculate the implicit expression, which is unstable and time consuming at the same time, for the sake of making expression decoupled, analytical formulation is required to make it explicit. Therefore, the implicit current - voltage expression is converted as an explicit one by applying the technique to solve the voltage as a function of current and vice versa, it is intended to make use of popular strategy as suggested by J. Amit, S. Sandeep, K. Avinashi [16], Villegas [17], K. Roberts, S. R. Valluri [18] that is known as Lambert W function.

For calculating $\boldsymbol{R s}$ :

$$
\mathbf{R s}=\mathbf{A}\left(\mathbf{W}_{-1}(B \exp (C))-(D+C)\right)
$$

Where,

$$
\begin{gathered}
A=\frac{a V_{T}}{I_{m p}} \\
B=-\frac{V_{m p}\left(2 I_{m p}-I_{s c}\right)}{V_{m p} I_{s c}+V_{o c}\left(I_{m p}-I_{s c}\right)} \\
C=-\frac{2 V_{m p}-V_{o c}}{a V_{T}}+\frac{\left(V_{m p} I_{s c}-V_{o c} I_{m p}\right)}{\left(V_{m p} I_{s c}+V_{o c}\left(I_{m p}-I_{s c}\right)\right)} \\
D=\frac{V_{m p}-V_{o c}}{a V_{T}}
\end{gathered}
$$

For calculating $\boldsymbol{R s h}$ :

$\mathbf{R}_{\mathrm{sh}}=\frac{\left(\mathbf{V}_{\mathrm{mp}}-\mathbf{I}_{\mathrm{mp}} \mathbf{R}_{\mathrm{s}}\right)\left(\mathbf{V}_{\mathrm{mp}}-\mathbf{R}_{\mathrm{s}}\left(\mathbf{I}_{\mathrm{sc}}-\mathbf{I}_{\mathrm{mp}}\right)-\mathbf{a} \mathbf{V}_{\mathrm{T}}\right)}{\left(\mathbf{V}_{\mathrm{mp}}-\mathbf{I}_{\mathrm{mp}} \mathbf{R}_{\mathrm{s}}\right)\left(\mathbf{I}_{\mathrm{sc}}-\mathbf{I}_{\mathrm{mp}}\right)-\mathbf{a} \mathbf{V}_{\mathrm{T}} \mathbf{I}_{\mathrm{mp}}}$

For calculating $\boldsymbol{I}_{\boldsymbol{0}}$

$$
\mathbf{I}_{0}=\frac{\left(\mathbf{R}_{\mathrm{sh}}+\mathbf{R}_{\mathrm{s}}\right) \mathbf{I}_{\mathrm{sc}}-\mathbf{V}_{\mathrm{oc}}}{\mathbf{R}_{\mathrm{sh}} \exp \left(\frac{\mathbf{V}_{\mathrm{oc}}}{\mathrm{a} \mathbf{V}_{\mathrm{T}}}\right)}
$$

For calculating $\boldsymbol{I}_{\boldsymbol{L}}$ :

$$
\mathbf{I}_{\mathbf{L}}=\frac{\mathbf{R}_{\mathrm{sh}}+\mathbf{R}_{\mathrm{s}}}{\mathbf{R}_{\mathrm{sh}}} \mathbf{I}_{\mathrm{sc}}
$$

\section{Methodology}

\subsection{Parameter identification and calculation from manufacturer's datasheet}

In order to evaluate the unknown parameters $\left(\mathrm{I}_{\mathrm{L}}, \mathrm{I}_{\mathrm{O}}\right.$, Rs, Rsh) and to simplify the calculations for specific model, P. M. Cuce, E. Cuce [19] elaborated that the ideality factor should be considered as generic value which is suggested for monocrystalline cell type as a = 1.2 and is independent of any temperature and irradiation. The following procedure is followed for calculating the parameters from manufacturer's datasheet. 
1) Approximating the ideality factor a as 1.2 for Monocrystalline Cell

2) Calculating the Series Resistance Rs with Equation (8)

Calculating the Shunt Resistance Rsh with Equation (10)

3) Calculating the Saturation Current $\boldsymbol{I}_{\boldsymbol{O}}$ with Equation (11)

4) Calculating the Photodiode Current $\boldsymbol{I}_{\boldsymbol{L}}$ with Equation (12)

The electrical characteristics are given in the TABLE I, which demonstrates the perquisite data for insertion in to the expressions. The input parameters from the datasheet at (STC) Standard Test Conditions are 1000 $\mathrm{W} / \mathrm{m} 2$ incident normal radiance, Cell temperature is 25 ${ }^{0} \mathrm{C}$ and Air Mass AM1.5g.

Table 1. Electrical specifications of ixolar solarmd slmd481h081

\begin{tabular}{|c|c|c|}
\hline $\begin{array}{r}\text { I - V Curve } \\
\text { Characteristics }\end{array}$ & Specifications & Units \\
\hline $\begin{array}{l}\text { Open Circuit } \\
\text { Voltage (Voc) }\end{array}$ & 5.04 & V \\
\hline $\begin{array}{l}\text { Short Circuit } \\
\text { Current (Isc) }\end{array}$ & 0.2 & A \\
\hline $\begin{array}{l}\text { Voltage at } \\
\text { maximum power point } \\
\text { (Vmpp) }\end{array}$ & 4.0 & V \\
\hline $\begin{array}{l}\text { Current at } \\
\text { maximum power point } \\
\text { (Impp) }\end{array}$ & 0.178 & A \\
\hline $\begin{array}{l}\text { Maximum Peak } \\
\text { Power (Pmpp) }\end{array}$ & 0.714 & W \\
\hline $\begin{array}{c}\text { Temperature } \\
\text { Coefficients of Isc } \\
\text { (alpha) }\end{array}$ & 0.12 & $K^{\mathrm{mA} /\left(\mathrm{cm}^{2}\right)}$ \\
\hline $\begin{array}{l}\text { Temperature } \\
\text { Coefficient of Voc } \\
\text { (beta) }\end{array}$ & -2.1 & $\mathrm{mV} / \mathrm{K}$ \\
\hline
\end{tabular}

The obtained parameters are demonstrated in TABLE II, where the unknown parameters have been calculated by the defined equations and pushing the ideality factor as constant and independent.

Table 2. Calculated parameters of ixolar solarmd slmd481h081

\begin{tabular}{|c|c|}
\hline Parameters & Calculated Values \\
\hline $\mathrm{I}_{0}$ & $9.0837 \mathrm{e}-10$ \\
\hline $\mathrm{I}_{\mathrm{L}}$ & 0.2009 \\
\hline $\mathrm{Rs}$ & 1.7795 \\
\hline Rsh & 398.4280 \\
\hline $\mathrm{a}$ & 1.2 \\
\hline
\end{tabular}

\subsection{Simulating the solar equivalent circuit}

In this paper, the commercial solar cell iXolar SolarMD SLMD481H08L [20] is being selected for analyzing $\mathrm{I}-\mathrm{V}$ and $\mathrm{P}-\mathrm{V}$ curves based on mathematical formulation and using the Linear Technology's LTSpice (Linear Technology Simulation Program with Integrated Circuit Emphasis) software. However, the obtained values will be modelled on the solar equivalent circuit for evolving the behavior of solar module on simulator. As defined in section IV. A, the input parameters have been calculated for modelling and simulation purpose for solar equivalent circuit as shown in Fig. 5.

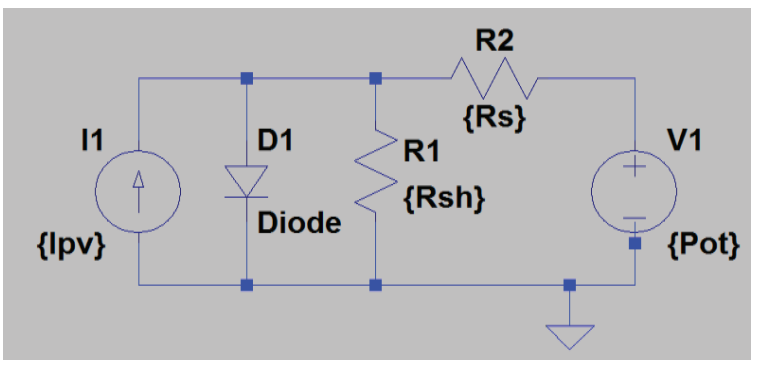

Fig. 5. Single diode Equivalent circuit for iXolar SolarMD SLMD481H08L

\section{Results and discussions}

\section{$5.1 \mathrm{I}-\mathrm{V}$ and $\mathrm{P}-\mathrm{V}$ curve simulation}

The generated $\mathrm{I}-\mathrm{V}$ and $\mathrm{P}-\mathrm{V}$ curve for commercial solar cell has been plotted as demonstrated in Fig. 6 and Fig. 7. The simulations are mathematically formulated based on the datasheet information. These plots are being further simulated based on two variations for solar equivalent circuit. The environment dependence has been modelled to analyze the PV cell response and the characteristics points to adequate the output performance of the cell. For this purpose, the temperature and irradiations levels are adopted to configure the system response in the real-time environment.

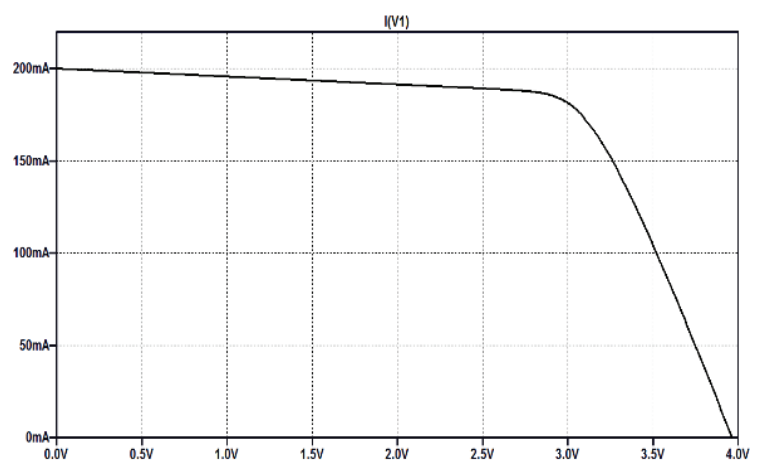

Fig. 6. I - V curve of Solar Equivalent Circuit of iXolar SolarMD SLMD481H08L 


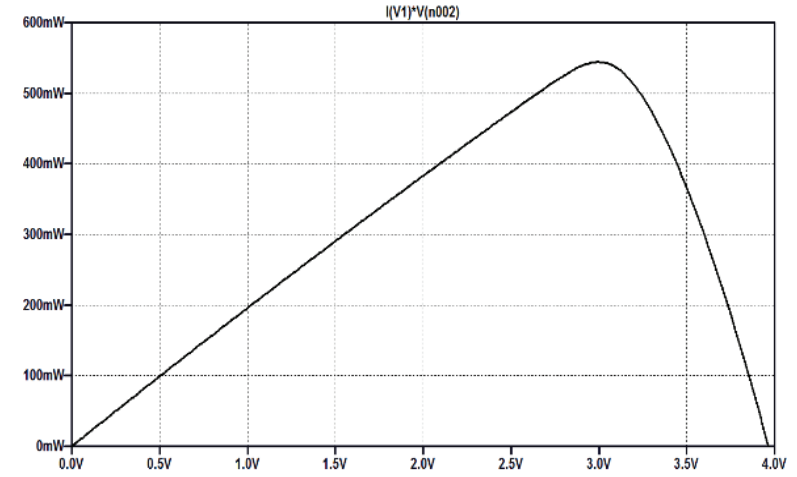

Fig. 7. $\mathrm{P}-\mathrm{V}$ curve of Solar Equivalent Circuit of iXolar SolarMD SLMD481H08L

\subsection{Effect of solar irradiation on $i-v$ curve}

The simulation is being performed on the same solar circuit for different levels of solar irradiation, which varies from $200 \mathrm{~W} / \mathrm{m}^{2}$ to $1000 \mathrm{~W} / \mathrm{m}^{2}$ by maintaining the temperature constant at $25{ }^{\circ} \mathrm{C}$. It can be seen in Fig. 8, that the generated current depends on the incident light, as long as the irradiation is increasing the current also increases. As there is slight change of voltage with respect to the increment of the current.

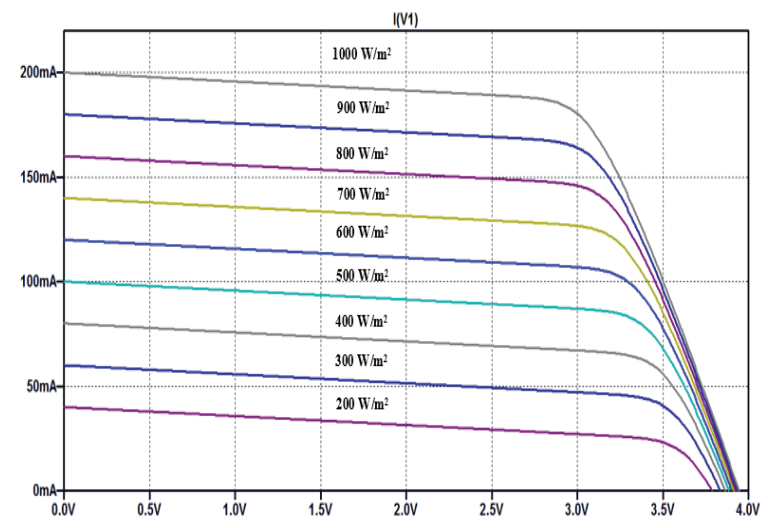

Fig. 8. Solar Irradiation levels from $200 \mathrm{~W} / \mathrm{m}^{2}$ to $1000 \mathrm{~W} / \mathrm{m}^{2}$ at $25^{0} \mathrm{C}$

\subsection{Effect of temperature on I - V and P - V curve.}

In this simulation, the temperature is being varied from $15{ }^{\circ} \mathrm{C}$ to $85^{\circ} \mathrm{C}$ and keeping the irradiation level constant at $1000 \mathrm{~W} / \mathrm{m}^{2}$. Fig. 9 and Fig. 10, shows the I$\mathrm{V}$ and $\mathrm{P}-\mathrm{V}$ curve generated on different temperature ranges. As it is clearly indicated that by varying the temperature from low to high, the voltage is being affected. Increasing the temperature causing the decreased voltage and maximum power point at the same time. While the current generated by incident light remained constant.

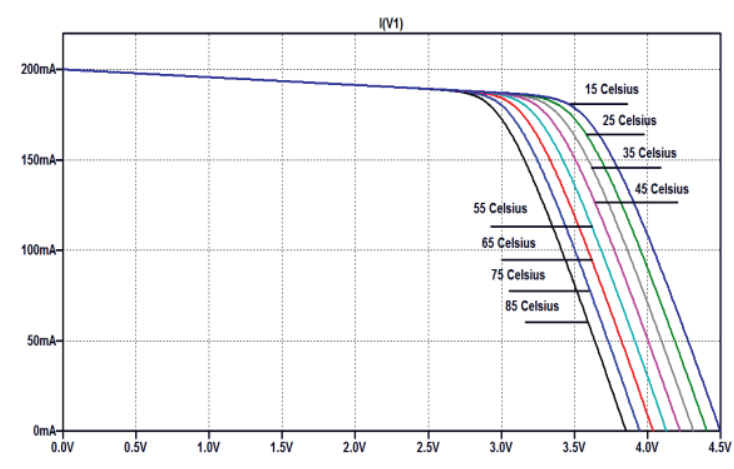

Fig. 9. I - V Characteristics for Temperature variation between $15^{\circ} \mathrm{C}$ to $85^{\circ} \mathrm{C}$ at $1000 \mathrm{~W} / \mathrm{m}^{2}$

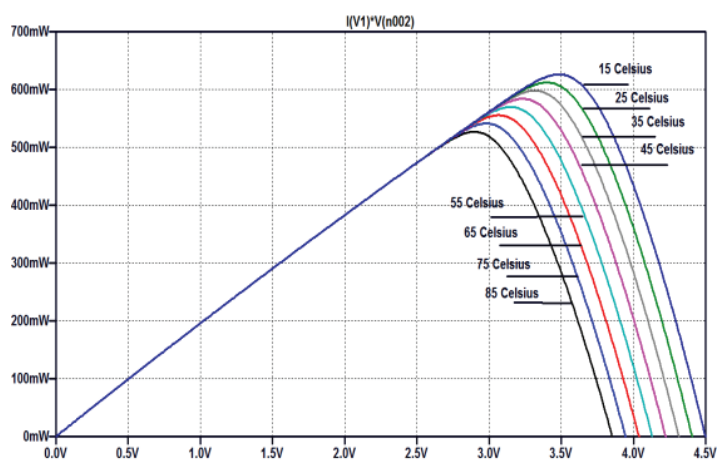

Fig. 10. $\mathrm{P}-\mathrm{V}$ Characteristics for Temperature variation between $15^{0} \mathrm{C}$ to $85^{0} \mathrm{C}$ at $1000 \mathrm{~W} / \mathrm{m}^{2}$

\section{Conclusion}

In this research work, the commercial solar cell is being examined to predict the solar cell response on the simulator based on the $\mathrm{I}-\mathrm{V}$ and $\mathrm{P}-\mathrm{V}$ characteristics. For such study, the solar cell is being modelled as a single diode equivalent circuit (1M5P), the only source available is the manufacturer's datasheet that is being considered to extract the unknown parameters. Certain calculation and explicit expressions have been performed to get most of the optimal values of the module. This way the calculation is being done on the Matlab software and the obtained parameters were simulated on LTSpice simulator on the equivalent circuit. The results have been analyzed on the two cases; one on the temperature variation and keeping irradiation constant and second on the irradiation levels keeping temperature constant. The plots of I -V curves indicate that as far as temperature increases the cell current slightly increases and the voltage is being decreased. It is observed that $\mathrm{P}-\mathrm{V}$ characteristics of solar cell denotes the decrease in voltage as the temperature is being decreased which proportionally affects the power output of the cell. However, the increment in the irradiation levels also increases the output power. Finally, this simulation based study provides the end users to establish the realistic mathematical modelling of solar cell, panel or an array to estimate the electrical behavior of PV systems for planning their own systems.

\footnotetext{
*Corresponding author: adila@eng.unideb.hu
} 


\section{References}

[1] Fuels, The End of Fossil. Ecotrcity Britain's Greenest Energy, https://www.ecotricity.co.uk/our-green-energy/energyindependence/the-end-of-fossil-fuels, (Date of Access: November 2016).

[2] A. S. Adila, A. Husam, J. H. Sana G. Husi. "Estimation of minimum output power threshold for energy harvesting module: An inspection of battery and charging parameters of cell phones." Proceedings of $4^{\text {th }}$ International Mechatronic Student MicroConference Budapest, 56-71, 2017.

[3] REN21. Renewables Global Status Report 2016. Paris: REN21 Secretrait: REN21 Publications, 2016.

[4] M. G. Vilalva, J. R. Gazoli, E. R. Filho, "Comprehensive approach to modeling and simulation of photovoltaic arrays",IEEE Transactions on Power Electronics, Vol. 24, No. 5, 1198-1208, May 2009.

[5] A. S. Sedra, K. C. Smith, Microelectronic Circuits, Oxford University Press, London, U.K. 2006.

[6] M. A. Eltawil, Z. Zhao, "Grid-connected photovoltaic power systems: Technical and potential problems- A review", Renewable and Sustainiable Energy Reviews, Vol. 14, No. 1, 112-129, Jan 2010.

[7] Union of Concerned Scientists- Science for a healthy planet and safer world. "How solar panels work", http://ucsusa.org/, (Date of Access: April 2016).

[8] J. Bikaneria, S. P. Joshi,A. R. Joshi, "Modeling and simulation of a pv cellusing one-diode model", International Journal of Scientifc Research Publications, Vol. 3, No. 10, 1-4, Oct 2013.

[9] E. M. G. Rodrigues, R. Melicio, V. M. F. Mendes, J. P. S. Catalao. "Simulation of a Solar Cell considering Single-Diode Equivalent Circuit Model." Renewable Energy and Power Quality Journal Vol. 1. No. 9, 369-373, 2011.
[10] T. T. Yetayew, T. R. Jyothsna,. "Improved single-diode modeling approach for photovoltaic modules using datasheet." Annual IEEE India Conference (INDICON). Bombay, 1-6, 2013.

[11] J. Cubas, S. Pindado, C. D. Manuel. "Explicit Expressions for Solar Panel Equivalent Circuit Paramaters Based on nalytical Formulation and the Lambert W-Function ." Energies Vol.7, No.7 4098-4115, 2014.

[12] G. R. Walker. "Evaluating MPPT topologies using a Matlab PV model." Journal of Electrical \& Electronics Engineering Vol. 21, No.1, 49-56, 2001.

[13] M. Azzouzi, D. Popescu, M. Bouchahdane. "Modeling of Electrical Characteristics of Photovoltaic Cell." Journal of Clean Energy Technologies Vol.4, No.6, 414-419, 2016.

[14] M. Wolf, H. Rauschenbach,. "Series resistance effect on solar cll measurements." Advance Energy Conversions 3 (1963): 455-479.

[15] A. Wafaa, A. M. Ashraf, A. Fouad, S. Saad,. "Mathematical Model for Photovoltaic Cells." Leonardo Journal of Sciences Vol.12, No. 23, 13-28, 2013.

[16] J. Amit, S. Sandeep, K. Avinashi,. "Solar cell array parameters using Lambert W-function." Solar Energy Material \& Solar Cells 90, 25-31, 2006.

[17] D. Villegas, "Analysis of solar cell using the Lambert W function with Maple." Proceedings of SPIE - Energy Harvesting and Storage: Materials, Devices, and Applications V. Baltimore, Vol. 9115, 2014.

[18] K. Roberts, S. R. Valluri. "Solar Cells and the Lambert W Function." Celebrating 20 years of the Lambert $W$ function. London, Canada, 2016.

[19] P. M. Cuce, E. Cuce,. "A novel model of photovoltaic modules for parameter estimation and thermodynamic assesment." International Journal of Low-Carbon Technology Vol. 7, 159$165,2011$.

[20] iXolar SolarMD SLMD481H08L,Available online http://ixapps.ixys.com/DataSheet/ixys_solar.pdf (Date of Access: January 2017). 